\title{
Study of Preliminary Phytochemical Screening and Antibacterial Activity of Tribulus terretris against Selected Pathogenic Microorganisms *Sonam Pandey
}

Department of Research, Priyamvada Birla Cancer Research Institute, Satna, Madhya Pradesh, India

\begin{abstract}
Medicinal herbs have a long history in improving human health and curing various diseases. A wide interest has been made for researchers using herbal material in identification of the active components and verification of their efficiency. We evaluated the aqueous and methanol extracts of $T$. terrestris for the phytochemical content and its antimicrobial activity. Phytochemical screening of the extracts revealed the presence of alkaloids flavonoids, saponins, anthraquinone, terpenoids, tannins, reducing sugar, and Cardiac Glycosides, etc. Disc diffusion method determined antibacterial effect of $T$. terrestris extracts. Methanolic extract have shown better inhibition than aqueous, again all the tested pathogens. Our results indicate that $T$. terrestris has potential therapeutic phytochemicals, which can be used as an alternative medicine for human health.
\end{abstract}

Keywords: T. terrestris; Phytochemical; Antibacterial agent; Broad spectrum

\section{Introduction}

Starting from the ancient time, medicinal plants have been used to prevent and treat various health problems. Plants are still an independent source of medication in the contemporary health care delivery system. Their role is twofold in the development of medicines and served as a natural blue print for the development of new drugs [1-3]. In recent years, the growing demand for herbal products has led to a quantum jump in volume of plant materials traded across the countries. Therefore, the use and history of herbs dates back to the time of early man, who had the crudest tools as his implements and use stones to start his fire. They used herbs in their raw and cooked forms to keep fit. Since that time, the use of herbs has been known and accepted by all nations and has been known also as the first art of treatment available to man [4].

Secondary plant metabolite (Phytochemicals), previously with unknown pharmacological activities, has been extensively investigated as a source of medicinal agents [5]. Some of the active principles singly or in combination inhibit greatly the life processes of microbes, especially the disease causing ones. They do this by binding their protein molecules, acting as chelating agents (selective binding polyvalent metal ions so that the latter loses its biological activities), altering their biochemical systems, preventing utilization of available interests to the microorganisms, other causes inflammation analysis of microbial cells [6].

Tribulus terrestris (Puncture Vine, Caltrop, Yellow Vine and Goat head) is a flowering plant of the Zygophyllaceae family, native to warm temperature and tropical regions of the old world in Southern Europe, Southern Asia, Africa, India, and Northern Australia. It can thrive even in desert climates and poor soil [7]. In Iraq, T. terrestris is used in folk medicine as tonic, aphrodisiac, analgesic, astringent, stomachic, anti-hypertensive, diuretic, lithontriptic and urinary antiinfectives [8]. Hence the purpose of this study was to screen the major phytochemical constituents and evaluate antimicrobial activity of the leaf extracts to support the traditional therapeutic claim and to provide base line information for the scientific communities to carry on further study.

\section{Materials and Methods}

All the chemicals and solvents used in experiment were of analytical grade.

\section{Plant collection and identification}

Fresh plant parts were collected randomly from local herbal botanical garden of Bhopal, Madhya Pradesh, India. The taxonomic identities of the plant Tribulus terrestris was confirmed by botanist Dr. S.S. Khan (Voucher Specimen No: SPTT/010/2010.), Department of Botany, Safia Science College, Bhopal, Madhya Pradesh, India. Fresh plant materials were washed under running tap water, air dried and then homogenized to fine powder and stored in airtight bottles.

\section{Extraction of plant}

Aqueous extraction: $10 \mathrm{~g}$ of powdered sample was dissolved in 100 $\mathrm{ml}$ of distilled water and boiled for $2 \mathrm{~h}$ on slow heat. The residue was removed by filtering through 8 layers of muslin cloth; the filtrate was then centrifuged at $5000 \mathrm{~g}$ for $10 \mathrm{~min}$. The supernatant was collected and further boiled till the volume was reduced to one-fourth of the original volume of the solvent used [that was $100 \mathrm{ml}$ ] giving the concentration of $400 \mathrm{mg} / \mathrm{ml}$ [9].

Ethanol extraction: Ten grams of powdered sample was dissolved in $100 \mathrm{ml}$ of ethanol in a conical flask, plugged with cotton wool and then kept on a rotary shaker at 190-220 rpm for $24 \mathrm{~h}$. The supernatant was collected slowly and evaporated in wide mouthed evaporating bowls at room temperature for 2-3 days till the final volume was reduced to one fourth of the original volume of the solvent used [that was $100 \mathrm{ml}$ ] giving the concentration of $400 \mathrm{mg} / \mathrm{ml}$ [9], and stored at $4^{\circ} \mathrm{C}$ in airtight bottles.

\section{Phytochemical analysis}

Phytochemical analysis of all the samples was determined as follows:

*Corresponding author: Sonam Pandey, Department of Research, Priyamvada Birla Cancer Research Institute, Satna, Madhya Pradesh, India, Tel: +91 9424385285; Fax: +91 7672 400200; E-mail: sonam_research@ymail.com

Received September 23, 2014; Accepted November 20, 2014; Published November 27, 2014

Citation: Pandey S (2014) Study of Preliminary Phytochemical Screening and Antibacterial Activity of Tribulus terretris against Selected Pathogenic Microorganisms. J Bioanal Biomed S12: 001. doi:10.4172/1948-593X.S12-001

Copyright: () 2014 Pandey S. This is an open-access article distributed under the terms of the Creative Commons Attribution License, which permits unrestricted use, distribution, and reproduction in any medium, provided the original author and source are credited. 
Molisch's test for Carbohydrates: Five hundred milligram of powdered sample was taken and dissolved in $5 \mathrm{ml}$ of distilled water and then filtered. Filtrate was added with few drops of Molisch's reagent, followed by addition of $1 \mathrm{ml}$ of conc. $\mathrm{H}_{2} \mathrm{SO}_{4}$ by the side of the test tube. After two minutes, $5 \mathrm{ml}$ of distilled water was added. Red or dull violet colour formation at the interphase of the two layers was taken as positive test [10].

Test for alkaloids: $100 \mathrm{mg}$ of powdered sample was dissolved in $5 \mathrm{ml}$ of methanol and then filtered. Then $2 \mathrm{ml}$ of filtrate was mixed with $5 \mathrm{ml}$ of $1 \%$ aqueous $\mathrm{HCl}$. One millilitre of mixture was taken separately in two test tubes. Few drops of Dragendorff's reagent were added in one tube and occurrence of orange-red precipitate was taken as positive. To the second tube Mayer's reagent was added and appearance of buff-colour precipitate was taken as positive test for the presence of alkaloids [11].

Liebermann-Burchard test for steroids: $200 \mathrm{mg}$ of powder sample was dissolved in $2 \mathrm{ml}$ of acetic acid separately; solutions were cooled followed by the addition of few drops of concentrated $\mathrm{H}_{2} \mathrm{SO}_{4}$. Colour development from violet to blue or bluish-green was taken as positive test steroidal ring [11].

Test for saponins: One gram of powdered sample was boiled in $10 \mathrm{ml}$ of distilled water and then filtered. $3 \mathrm{ml}$ of distilled water was added to filtrate and shaken vigorously for about $5 \mathrm{~min}$. Formation of foam after shaking was taken as a confirmation for the presence of saponins [11].

Shinoda's test for flavonoids: Five hundred milligram of sample was dissolved in $5 \mathrm{ml}$ of ethanol, slightly warmed and then filtered. Few pieces of magnesium chips were added to the filtrate followed by addition of few drops of concentrated $\mathrm{HCl}$. A pink, orange, or red to purple coloration was taken as a confirmation for the presence of flavonoids [12].

Test for tannins: $500 \mathrm{mg}$ of powdered sample was mixed with $10 \mathrm{ml}$ of distilled water and then filtered followed by the addition of few drops of $1 \%$ ferric chloride solution. Occurrence of a blue-black, green or blue-green precipitate indicates the presence of tannins [12].

\section{Antimicrobial assay}

Bacterial strains: The aqueous and ethanol extracts of Tribulus terrestris fruit of $1000 \mathrm{mg} / \mathrm{mL}, 750 \mathrm{mg} / \mathrm{mL}, 500 \mathrm{mg} / \mathrm{mL}$ and $250 \mathrm{mg} /$ $\mathrm{mL}$ concentrations were tested against gram positive Bacillus subtilius (ATCC 11778), Staphylococcus aureus (ATCC 25923), Streptococcus epidermidis(ATCC 24676) and Gram-negative E. coli (ATCC 25922), Shigella flexneri (ATCC 11435), Pseudomonas aeruginosa (ATCC 17440) for their antimicrobial activity.All the bacterial strains were obtained from National Chemical Laboratory, Pune, India. The bacteria were grown in the nutrient broth at $37^{\circ} \mathrm{C}$ and maintained on nutrient agar slants at $4^{\circ} \mathrm{C}$.

Preparation of inoculums (Muller Hinton media): One single colony of each type of microorganism (from the nutrient agar stock culture) was taken with a sterile loop, and was transferred into $10 \mathrm{~mL}$ sterile nutrient broth. The broth cultures were incubated in a shaking incubator at $37^{\circ} \mathrm{C}$ for $16-20 \mathrm{~h}$.

Antibacterial susceptibility test: Disc diffusion assay: The antimicrobial activity of crude extracts of plants was initially assessed against the six tested microorganisms using the agar diffusion method as recommended by the Clinical Laboratory Institute. Nutrient agar medium was prepared by suspending nutrient agar (Merck) $20 \mathrm{~g} / \mathrm{L}$ in distilled water. The $\mathrm{pH}$ value of the media was adjusted to 7.0, autoclaved and allowed to cool up to $45^{\circ} \mathrm{C}$. The media was seeded with $10^{6} \mathrm{CFU} / \mathrm{mL}$ prepared inoculums. Subsequently, the seeded medium $(75-80 \mathrm{~mL})$ was poured into pre-labelled Petri plates $($ diameter $=14 \mathrm{~cm})$ and allowed to solidify [13].

Each herbal extract reconstituted in DMSO to a concentration of $25,50,75,100 \mathrm{mg} / \mathrm{ml}(\mathrm{w} / \mathrm{v} ; \mathrm{mg} / \mathrm{mL})$ was dispensed into the discs. The plates were then incubated at $37^{\circ} \mathrm{C}$ for $24 \mathrm{~h}$ for bacteria after which microbial growth was determined by measuring the diameter of the inhibition zone $(\mathrm{mm})$ using a ruler or caliperscale. Each experiment was performed in triplicate and repeatedtwice. Standard antibiotics $(5 \mu \mathrm{g})$ Gram-positive (TE-tetracycline, OF-ofloxacin, AZ-azithromycin, PCpiperacillin) and Gram-negative FU nitrofurantoin, GM-gentamicin, CX-cefotaxime, NF norfloxaci, $(5 \mu \mathrm{g} / \mathrm{disc})$ were prepared as positive control. Pure dimethyl sulfoxide (99.9\%) was used as negative control.

\section{Results and Discussion}

\section{Phytochemical screening}

As it is clearly indicated in the Table 1 below, preliminary phytochemical analysis showed alkaloids, saponnins, carotinoid and tannins detected in petroleum extract while phytosterols and saponins detected in aqueous and ethanol extract.

\section{Antibacterial activity}

Antimicrobial activity of Tribulus terretris fruit extracts in two different solvents has been tested against Gram positive and Gram negative bacterial strains. All figures summarize the microbial growth inhibition of aqueous and ethanolic extracts of Tribulus terrestris.

The results indicated that the different extracts of Tribulus terretris exhibit antibacterial activity. Tribulus terretris ethanolic extracts has shown higher activity than aqueousextract (Figures 1 and 2). Bacterial strains were tested in $25,50,75$, and $100 \mathrm{mg} / \mathrm{ml}$ ethanolic and aqueous extracts for $24 \mathrm{hrs}$ by disc diffusion assays. The poor activity at lower concentrations $(25-50 \mathrm{mg} / \mathrm{ml})$ may be attributed to the less solubility

\begin{tabular}{|c|c|c|c|c|}
\hline S.No. & Name of Tests & Tests/Reagents & TTAE & TTEE \\
\hline \multirow[t]{2}{*}{1} & \multirow[t]{2}{*}{ Reducing Sugar } & Fehlings test & + & + \\
\hline & & Molish test & + & + \\
\hline 2 & Glycosides & Borntrager's & + & + \\
\hline \multirow[t]{2}{*}{3} & \multirow[t]{2}{*}{ Alkaloids } & Dragendorff's test & _- & + \\
\hline & & Mayer's test & - & + \\
\hline 4 & Phytosterol & chloroform & - & + \\
\hline \multirow[t]{2}{*}{5} & \multirow[t]{2}{*}{ Steroidal compounds } & Salkowski's Test & - & + \\
\hline & & Lieberman's Test & - & + \\
\hline 6 & Saponins & Froth test & + & + \\
\hline \multirow[t]{3}{*}{7} & \multirow[t]{3}{*}{ Tennins } & Ferric chloride test & + & + \\
\hline & & Formaldehyde test & + & + \\
\hline & & Test for phlobatanins & + & + \\
\hline 8 & Fixed oils and Fats & Spot test & - & - \\
\hline \multirow[t]{3}{*}{9} & \multirow[t]{3}{*}{ Flavonoids } & Test for free flavanois & + & + \\
\hline & & Lead Acetate Test & + & + \\
\hline & & Sodium Hydroxide & + & + \\
\hline 10 & Phenolic compound & Ferric chloride test & + & + \\
\hline \multirow[t]{2}{*}{11} & \multirow[t]{2}{*}{ Protein and Amino acid } & Biuret Test & - & + \\
\hline & & Ninhydrin Test & - & + \\
\hline $\begin{array}{l}\text { Here, } \\
\text { TTEE= }\end{array}$ & $\begin{array}{l}\text { presence, } \quad-: \text { absen } \\
\text { ulus terretris ethanol }\end{array}$ & $\begin{array}{l}\text { TTAE=Tribulus } \\
\text { act }\end{array}$ & $s$ & \\
\hline
\end{tabular}




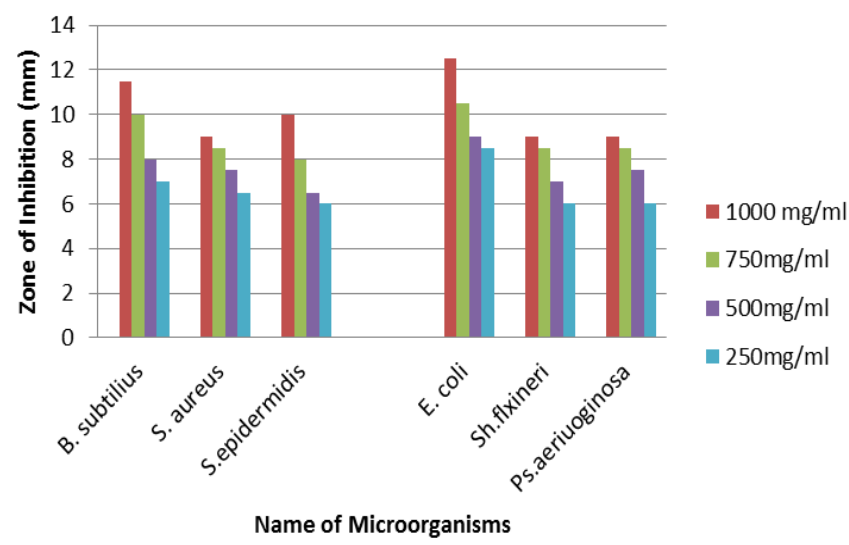

Figure 1: In vitro antibacterial activity of Tribulus terrestris ethanolic extract by disc diffusion test.

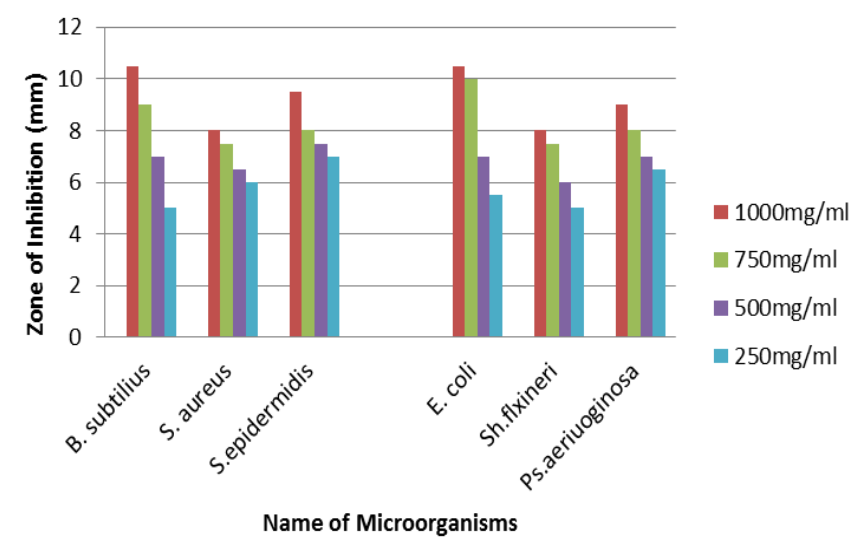

Figure 2: In vitro antibacterial activity of Tribulus terrestris aqueous extract by disc diffusion test.

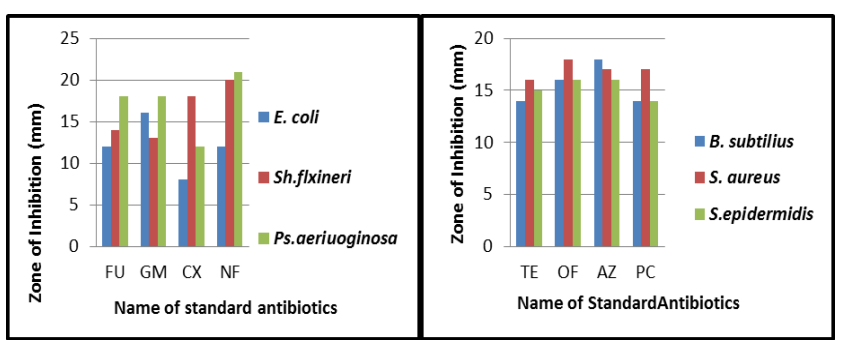

NOTE: TE-tetracycline, OF-ofloxacin, AZ-azithromycin, PC-piperacillin) FU nitrofurantoin, GM-gentamicin, CX-cefotaxime, NF norfloxaci

Figure 3: A-Antibacterial activity of standard antibiotic against Gram- negative bacteria. B-Antibacterial activity of standard antibiotic against Gram-positive bacteria.

of its active compounds, which may improve with stringent extraction procedures. At higher concentration $(75-100 \mathrm{mg} / \mathrm{ml})$ all the extracts showed significant antimicrobial activity.

It was observed that all extracts showed growth inhibition of various clinical isolates. Zone inhibition of all tested samples for Gram positive and Gram negative bacterial strains were compared to standard antibiotics which is broad spectrum antibiotic (Figure 3).

Result of the present study indicated that the alkaloid extracts of all the parts of $T$. terrestris have activity against both gram-positive and gram-negative bacteria indicative of the presence of broad spectrum antibiotic compounds.Many workers have reported on the antibacterial activity of natural products obtained from various sources of plant materials such as seeds[14], roots [15], plant parts [16-19] etc. Great attention is directed towards isolation, identification and synthesis of the natural products active against a wide variety of bacteria and fungi that cause diseases both in humans and animals. In this direction, the antimicrobial activity of ethanolicand aqueous extract of Tribulus terrestris herb was tested against four species of bacteria namely gram positive organisms like Bacillus subtitis, Staphylococcus aureus, S. epidermidis and gram negative organisms like E. coli, P. aeruginosa, and Sh. Flexineri.

In the present investigation, the antimicrobial activity of various test samples in comparison with standard antibiotics were determined and found to proceed in a dose-dependent manner for different bacterial strains. Those are becoming a clinical problem in hospital patients. Gram-positive bacteria, $S$. aureus is known to cause serious diseases such as pneumonia, meningitis etc., in hospital patients [2023]. E. coli and P. aeruginosac ause the Urinary Tract Infections (UTI), pulmonary tract infections, burns, wounds, dysentery-like diarrhoea and other blood infections and similar also true for S. epidermidis [24].

\section{Conclusion}

This study clearly indicates that extracts of the plants studied possess potent antimicrobial activity. The use of crude drug of such plant as an agent to control microbial pathogens needs further extensive research for their better economic and therapeutic utilization. Furthermore, it may help to discover new chemical classes of antibiotics that could serve as selective agents for the maintenance of animal or human health and provide biochemical tool for the study of infectious diseases. The presence of most general phytochemicals might be responsible for their therapeutic effects. It further reflects a hope for the development of many more novel chemotherapeutic agents or templates from such plants which in future may serve for the production of synthetically improved therapeutic agents.

\section{Acknowledgement}

The author is thankful to Dr. R.C. Agrawal and Research staff of Priyamvada Birla Cancer Research Centre, Satna (M.P), and India for their contribution in the piece of study. This study was supported by DST, New Delhi, India (Grant No. DST No.Latter No. SSD/SS/010/2010).

\section{References}

1. Addis $G$, Abebe $D$, Urga $K$ (2001) A survey of traditional medicinal plants in shirka district, ARSI zone. Ethio Pharm J 19: 30-35.

2. Duncan A, Okunji C (1999) New Antimicrobials of plant origin. IN: J.Janick perspectives on new crops and new uses, VA: ASHS PRESS, Alexandria, 6 : 457-462.

3. Asres K, Taddese S, Gebremariam T (2003) In vitro antimicrobial activities of some selected topically applied medicinal plants of Ethiopia. Ethio Pharm J 21: $34-45$.

4. Garrod LP, Lambert HP, Gray F (1981) Antibiotics and Chemotherapy. (5thedn) Edinburgh: Churchill Livingstone, 4: 501-512.

5. Kafaru E (1994) Immense Help from Natives Workshop. (1stedn) Elizabeth Kafaru, Lagos, Nigeria 11-14.

6. Krishnaraju AV, Rao TV, Sundararaju D, Vanisree M, Subbaraju GV, et al. (2005) Assessment of bioactivity of Indian medicinal plantsusing Brine shrimp (Altenaria salania) lethality assay. International Journal of Applied Science and Engineering 2: 125-134.

7. Usman $\mathrm{H}$, Abdulrahman FI, Ladan AA (2007) Phytochemical and Antimicrobia 
Citation: Pandey S (2014) Study of Preliminary Phytochemical Screening and Antibacterial Activity of Tribulus terretris against Selected Pathogenic Microorganisms. J Bioanal Biomed S12: 001. doi:10.4172/1948-593X.S12-001

Evaluation of Tribulus terrestris L (Zygophylaceae) Growing in Nigeria. J of biol Sci 2: 244-247

8. Saad Aldein SM (1986) Medicinal Herbs. (1 ${ }^{\text {st }}$ edition) Al-Shoun Al-Thaqafia AlAama for Publishing, Baghdad, 70.

9. Krishnaiah D, Sarbatly R, Bono A (2007) Phytochemical antioxidants for health and medicine - A move towards nature. Biotechnol Mol Biol Rev 1: 97-104.

10. Harborne JB (1973) Phytochemical Methods. (2ndedn) Chapman and Hill, London: $52-55$

11. Sofowora A (1993) Screening plants for bioactive agents. In: Medicinal Plants and Traditional Medicinal in Africa. ( $2^{\text {nd }}$ edition) Spectrum Books Ltd, Sunshine House, Ibadan, Nigeria 134-156.

12. Trease GE, Evans WC (2002) Pharmacognosy. (15thedn.)Springer, Berlin 214-394.

13. Bauer AW, Kirby WM, Sherris JC, Turck M (1966) Antibiotic susceptibility testing by a standardized single disk method. Am J Clin Pathol 45: 493-496.

14. Han X, Shen T, Lou H (2007) Dietry polyphenols and their biological significance. Int J Mol Sci 8: 950-988.

15. Ali SS, Kasoju N, Luthra A, Singh A, Sharanabasava H, et al. (2008) Indian medicinal herbs as sourceof antioxidants. Food Res Int 41: 1-15.
16. Wojdylo A, Oszminaski J, Czemerys R (2007) Antioxidant activity and phenolic compounds in 32selected herbs. Food Chem 105: 940-949

17. Dobner MJ, Schwaiger S, Jenewein IH, Stuppner H (2003) Antibacterial activity of Leontopodium alpinum (Edelweiss). J Ethnopharmacol 89: 301-303.

18. Baydar H, Sagdic O, Ozkan G, Karadogan T (2004) Antibacterial Activity and Composition of Essential Oils from Origanum, Thymbra and Satureja Species with Commercial Importance in Turkey. Food Control 15: 169-172.

19. Chandrasekaran M, Venkatesalu V (2004) Antibacterial and antifungal activity of Syzygium jambolanum seeds. J Ethnopharmacol 91: 105-108.

20. Tsuchiya H, Sato M, Miyazaki T, Fujiwara S, Tanigaki S, et al. (1996) Comparative study on the antibacterial activity of phytochemical flavanones against methicillin-resistant Staphylococcus aureus. J Ethnopharmacol 50: 27-34.

21. Mason TL, Wassermn BP (1987) Inactivation of red beet betaglucan synthase by inactive and oxidized phenolic compounds. Phytochemistry 26: 2197-2202.

22. Ya C, Gaffiney SH, Lilley TH, Haslam E (1988) Carbohydrate-polyphenol complexation: 553 .

23. Curran JP, Al-Salihi FL (1980) Neonatal staphylococcal scalded skin syndrome: massive outbreak due to an unusual phage type. Pediatrics 66: 285-290.

24. Ryan KJ, Ray CG (2004) Sherries medical microbiology: An introduction to infectious diseases. (4thedn) McGraw Hill, New York.
This article was originally published in a special issue, Development of Phyłochemicals as Drugs handled by Editor. Dr. Erik de Leeuw, University of Maryland, USA 